\title{
ACCOUNTING STUDENTS' PROFILE VERSUS ACADEMIC PERFORMANCE: A FIVE-YEAR ANALYSIS
}

\author{
E. Papageorgiou \\ Department: Accountancy \\ University of the Witwatersrand \\ Johannesburg, South Africa \\ e-mail: Elmarie.Papageorgiou@wits.ac.za
}

\section{ABSTRACT}

The purpose of the study was to explore first-year accounting students' profile $(\mathrm{N}=3075)$ in terms of academic performance over a period of five years (2010-2014) at a South African university. The objectives were to determine the impact of students' profile (age, gender, race) and the students' pre-university knowledge brought to lectures (language, subject choice, whether Accounting was a Grade 12 subject) on academic performance. A quantitative research method was used. The study concluded that student profile, in particular gender, race and pre-university knowledge of first-year accounting students, does have an impact on the academic performance. Interestingly, for the period 2010 to 2013, no correlations was found between Accounting I students' academic performance and languages other than English and Afrikaans but in 2014 significant correlations were found between Accounting I students' academic performance and two first languages; Sepedi and Sesotho. The findings identified trends for at-risk students consequently assisting to implement interventions to assist at-risk students to pass Accounting I. The study's limitations include, firstly, the use of only one university and, secondly, a sample size including only first-year Accounting students. The value of this study should enable the university to identify students who fit the profile in terms of passing Accounting I in their first year at an academic institution.

Key words: academic performance, gender, language, race, South Africa, student profile, university

\section{INTRODUCTION}

Accounting students' profile of self, career and employability can play a significant role in degree choices based on prior knowledge and of how potential accounting students perceive a career in accounting that could possibly influence future career paths. Degree and career paths are vital in matching the profile of accounting students with prior knowledge and insights of degree and career prospects (Papageorgiou, Callaghan, Coldwell and Joosub 2014). Students' career pathways have gained momentum since subject and career guidance have been introduced at school level together with 'open days' hosted at most of the South African 
academic institutions assisting scholars in guiding students in their degree choices and futures careers. Some students' profiles can often lead to students who become completely indecisive in choosing subjects for a degree, choosing a career and/or experiencing uncertainty among career choices that guarantee employability (Bullock-Yowell, Peterson, Reardon, Leierer and Reed 2011; Weatherby, Winne, MacAllister and Nesbit 2008; Eddy, Burke and Fiksenbaum 2008). While some students' profiles indicate that students who prefer to study towards becoming Chartered Accountants (CAs) indicate lower levels of subject indecision since the professional body together with academic institutions provide a fixed curriculum for the degree (SAICA 2016; Jordaan, Burger and Smithard 2009; Papageorgiou et al. 2014).

Over the past decade, student numbers have increased, wider variety in the prior knowledge of students have been perceived and the changing learning environment (referring to the digital environment) that placed yet more pressure on resources and facilities. These challenges have increased the desires for income cohort and brought about improved flexibility in modes of study, as well as further exploration in relation to quality and standards (Fry, Ketteridge and Marshall 2009). These factors in turn influence the academic performance of undergraduate students, student support systems, degree quality and mode of teaching (DoE 2002). An additional encounter facing higher education is the probability that students need to be more equipped and trained for the 'world of work' (Fry et al. 2009, 3).

Academic institutions may admit students who fulfil the requirements however due to the number of places available for the degree they are applying for only a select few are enrolled. Currently the norm is that students apply at more than one university to avoid disappointment and if accepted at one university it would free up a place at the other university/ies the student applied for. Universities have to rely on pre-university indicators, for example marks obtained in Grade 12, which will provide an indication whether or not students are eligible to register for the degrees they have chosen. Although universities provide a learning environment, facilities, lecturers and study material, all of which should be conducive to succeed at a university, the way in which students learn and adapt to student life can only be influenced to a certain degree. Biggs (1993) states that learning should not be viewed in isolation but forms part of other aspects such as teaching methods, curriculum, assessment, and students’ prior experiences and knowledge. Student learning refers to creating a learning environment in which students can learn effectively, which influence the learning approach and, eventually, academic performance and outcome (Booth, Luckett and Mladenovic 1999; Biggs 1993).

A model that indicates student learning processes, developed by Biggs (1985), consisting of three stages: presage, process and product was adapted for this study focusing only on the 
presage and product stages (indicated as non-shadowed areas) (uncontrollable factors), as illustrated in Figure 1. The first stage emphasises both the student profile, that is, the age, race and gender of students admitted to the university, and the pre-university knowledge that students bring to lectures which could influence academic performance. The second stage (see Figure 1 - indicated as shaded areas) (controllable factors) was not explored in this study since lecturers/educators can control the learning environment but not the presage stage. The model implies that the product stage can be altered or influenced to some degree through teaching methods and the learning approach to academic performance or product.

The objectives of this study were to explore (see Figure 1) the impact of the accounting student's profile admitted to the university (age, gender, race) and the pre-university knowledge (languages in Grade 12, Grade 12 subject choice, whether Accounting was a Grade 12 subject or not) on academic performance or outcome (measured in marks obtained in Accounting I). The motivation of the research was to establish if the demographics of students $(\mathrm{N}=3075)$ (Table 1) admitted to Accounting I for a period of five years (2010-2014) had an impact on students’ academic performance and, consequently, to recommend further research into trends and possible patterns in student profiles and pre-university knowledge versus academic performance. To address the objectives of the study, each of the factors were investigated that could have an impact on students' academic performance:

Part 1

Presage

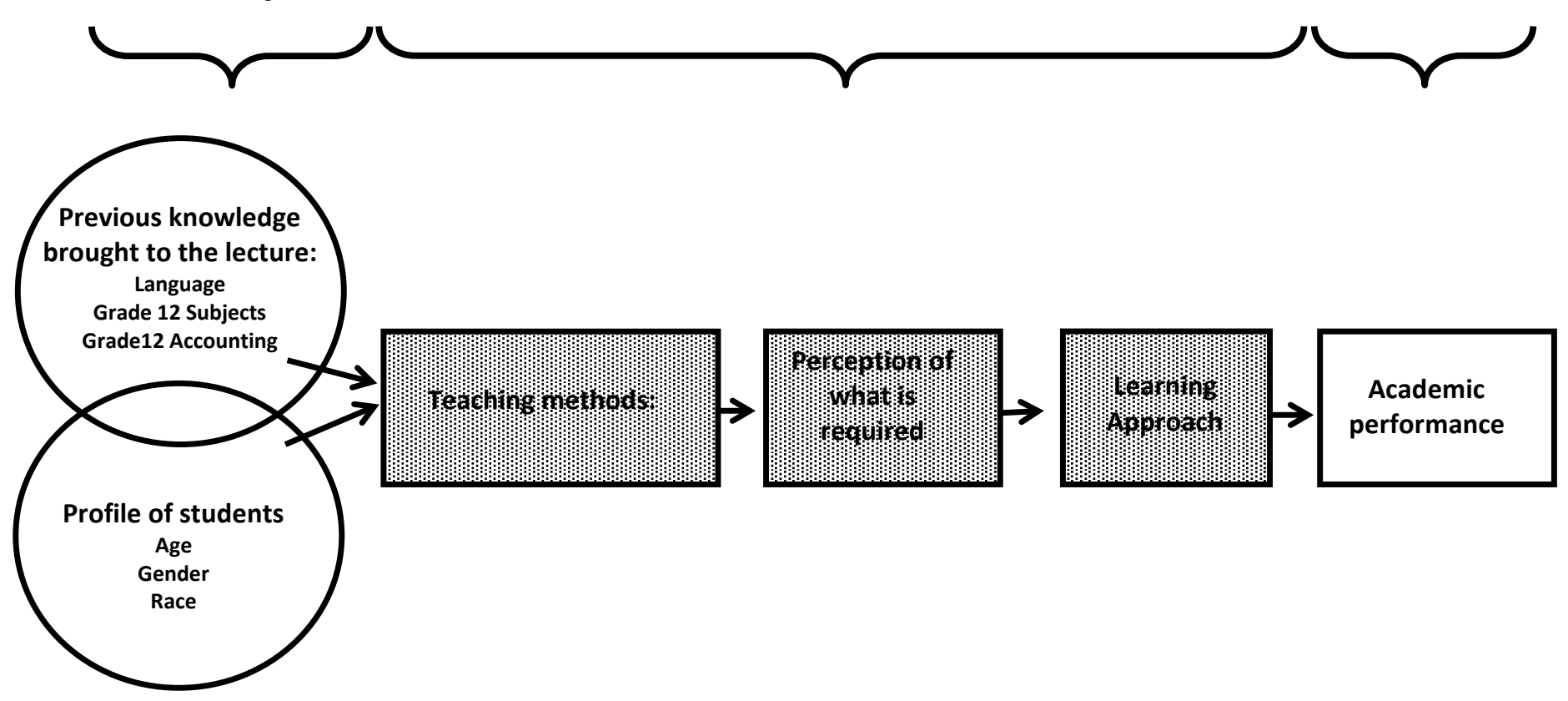

Part 2

Process
Part 3

Product

Source: Adapted from Biggs (1985)

Figure 1: Teaching and learning model: emphasis on students' profile and pre-university knowledge versus academic performance 
This art begins by reviewing the literature pertaining to the impact of students' profile on academic performance with particular reference to first-year accounting students. Next the research design is documented, thereafter a discussion on the findings of the study, followed by the conclusion, limitations, value of the study and recommendations.

\section{LITERATURE REVIEW}

There are currently twenty-three universities in South Africa, eleven universities of which are research intensive in conducting pure and applied research, six universities are of technology and the remaining six universities are comprehensive offering traditional programmes (Pitso 2013). The university under review is a public, urban, comprehensive university in South Africa. South African universities need to attract a variety of students who match the current demographics of the country, thus including students from different backgrounds, schooling systems, and income and socioeconomic groups. It is therefore essential to identify some of the determining factors, age, gender, race, language, Grade 12 subject choice and whether or not Accounting as a Grade 12 subject could influence students' academic performance in the various courses offered at universities.

Previous studies relating to student success factors investigated student profiles and the factors affecting academic performance in various disciplines. The following more recent Accounting studies were discussed by referring to student, lecturer and institution-related factors for academic success. Baard, Steenkamp, Frick and Kidd (2010) investigated factors influencing success in first-year Accounting with reference to the student profile, while Oosthuizen and Eiselen's (2012) study identified factors associated with first-year Accounting students' success. Steenkamp, Baard and Frick (2009) also investigated factors influencing success in first-year Accounting in terms of a comparison of lecturers' assumptions and students’ perceptions. Müller, Prinsloo and Du Plessis (2007) reported on a validation of successful first-year accounting students’ profile. Prinsloo and Van Rooyen (2007) explored a blended learning approach improving students' success in the teaching of second-year Accounting. Aidoo-Buameh and Ayagre (2013) analysed the impact of university accounting students' entrance marks on the academic performance. Wally-Dima and Mbekomiza's (2013) study examined the causes of gender differences in Accounting performance. Addow, Abubakar and Abukar (2013) investigated the link between English language proficiency and achievement for undergraduate Accounting students, while Balduf (2009) identified underachievement among college students and Akenbor's (2014) study studied institutional 
factors influencing the academic performance of students in principles of Accounting.

This study aims to explore the trends and possible patterns in the student profile of firstyear Accounting students in terms of academic performance over a period of five years at a South African university. The student profile includes age, gender, race, the eleven official SA languages, 62 different Grade 12 subjects and whether students had Accounting as a Grade 12 subject. As shown in Figure 1, the presage and product stages were investigated to determine whether a relationship exists between the profile of first-year Accounting students and academic performance.

Müller et al. (2007) suggest that a student who is less than 30 years of age is more likely to pass Accounting than students who are older than 30 years. According to Barlett, Peel and Pendlebury (1993), Accounting students' age as a predictor of academic performance has largely been ignored. The study by Wally-Dima and Mbekomiza (2013) investigated gender differences in relation to academic achievement among students enrolled for Accounting at a university in Botswana. The results revealed that female students perform better in terms of their academic performance compared with their male counterparts, since female students 'work harder to break into the historically male dominated accounting profession and they mature and become more serious with their studies than male students' (Wally-Dima and Mbekomiza 2013, 23). Baard et al. (2010) also investigated gender differences in relation to academic achievement among accounting students at a South African university and found that females were more successful than males.

Addow et al. (2013) investigated the relationship between English language proficiency and academic achievement among Business and Accounting students. The results showed that 'English language proficiency correlates positively with academic success' (Addow et al. 2013, 64). Tailab (2013) explored obstacles associated with low student academic achievement in introductory courses in the College of Accounting at a university in Libya. The results indicated that one of the major obstacles was students' lack of English language proficiency. AidooBuameh and Ayagre (2013), who conducted their research at the Central University College in Ghana, investigated relationships between Accounting students admitted to the university predominantly in terms of the prior knowledge they bring to lectures and their academic performance. The results confirmed a correlation between Mathematics as a Grade 12 subject and academic performance but no correlation was found between pre-university English and academic performance.

Baard et al. (2010) highlighted a number of factors which they considered to influence the success of first-year Accounting students. They found, firstly, that the higher the National 
Senior Certificate (NSC) $)^{1}$ mark the more likely the student is to be successful and, secondly, students who did not have English as a first language are more likely to obtain a lower mark for Accounting. Mills, Heyworth and Rosenwax (2009) identified a number of factors associated with first-year students' success; the most influential being an average and above average Grade 12 mark, English as a first language and Accounting as a Grade 12 subject. Lourens and Smit (2003) confirmed that students’ aggregate Grade 12 mark and main fields of learning are significant predictors of success in their first year of study at an academic institution.

A study by Akenbor (2014) investigated institutional factors influencing the academic performance of accounting students in their first year at the Federal University Otuoke in Nigeria. One of Akenbor's $(2014,15)$ recommendations was that 'pre-university Accounting with a minimum pass, as a key success factor for achieving in Accounting, should be part of the requirements for admitting students to the Accounting programme'. Currently, the university in this study does not require Accounting as a Grade 12 subject in order to be admitted to the Accounting commerce (CA) and the General commerce (non-CA) degrees. Baard et al. (2010), however, indicate in this regard that students who had prior knowledge in Accounting are more successful than students with no Accounting in school. Other studies (Müller et al. 2007; Du Plessis, Müller and Prinsloo 2005) contradict from the findings of Akenbor (2014), Baard et al. (2010) and Rowlands (1988) and indicated that pre-university knowledge of Accounting does not significantly influence the academic performance of Accounting students in their first year. In a study aimed at understanding the academic performance and advancement of first-year accounting students at a university in Scotland, Duff (2004) concluded the best predictor of academic performance is prior achievement before entering the academic institution.

\section{METHODOLOGY}

This research study used a quantitative research method, focused on accounting students' profile entering the university and the impact on their academic performance at the end of the academic year. The group selected was Accounting students registered for both the Accounting commerce (CA) and General commerce (non-CA) degrees in their first year of study. Data was collected over a period of five years, 2010 to 2014 (Table 1), from the university's central computer system; including the demographics of the students, marks obtained in the NSC exam and the final Accounting I marks. A minimum of a $\mathrm{C}$ symbol for Mathematics and English in the NSC exam is required in order to be accepted for the CA degree. Students enrolled for the CA degree have a higher Academic Points Score (APS) than students enrolled for the non-CA 
degree. The APS score is based on their NSC exam results with a heavier weighting being given to English and Mathematics results.

Table 1: First-year Accounting students 2010 to 2014

\begin{tabular}{|l|c|c|c|}
\hline \multicolumn{4}{|c|}{ First-year Accounting I students } \\
\hline \multicolumn{1}{|c|}{ Year } & Frequency & Valid Percent & Cumulative Percent \\
\hline 2010 & 470 & 15.3 & 15.3 \\
\hline 2011 & 489 & 15.9 & 31.2 \\
\hline 2012 & 509 & 16.6 & 47.7 \\
\hline 2013 & 656 & 21.3 & 69.1 \\
\hline 2014 & 951 & 30.9 & 100.0 \\
\hline Total & 3075 & 100.0 & \\
\hline
\end{tabular}

The sample consisted of 3075 first-year accounting students. An increase in students (49.5\%) from 2010 to 2014, almost doubling the number of students in the five years under review, was observed as a result of more students with the required APS score qualifying to register for the Accounting I course. Part-time students and students who deregistered from the Accounting I course were excluded from the sample, representing a small percentage of the sample under review. The students' academic performance was measured in terms of the final marks obtained in Accounting I expressed as a percentage out of 100. The final marks were made up of three tests (March, June and September), an exam (November), a project, tutorials and concept tests. The marks for the Grade 12 subjects were expressed as a percentage out of 100. The data was analysed using Statistical Package for the Social Sciences (IBM SPSS V23) to identify frequencies and to compare data across the different frequencies. Cross tabulations with an appropriate test for independence and a chi-square test were conducted to determine whether categorical variables were related. Descriptive analysis provided a very useful initial examination of the data and constituted the initial phase of the statistical analysis. In addition, a frequency distribution showed in absolute and relative (percentage) terms how often the different values of the variable were actually encountered in the sample. A one-way analysis (ANOVA) and a $t$-test were used to determine the differences between each of the student profile variables and academic performance.

\section{RESULTS AND DISCUSSION}

This section deals with the discussion of the results as per the results of the statistical analysis conducted (Illustrated in Tables 2 to 8 and Figures 2 and 3). 


\section{Age}

The students' age in this study varied from 19 to 21 years. It is assumed that age would have no effect on first-year Accounting students' academic performance, though the mean score (1921) could not be compared with any other age group. However, the current age group (19-21) might have displayed a significant difference if the part-time students had been included in the study. The number of part-time students varied for the period under review with an average of \pm 40 students per year. Part-time students were excluded from the study since the Grade 12 subjects written prior to 2010 (previously subjects were divided into higher and standard grades) were not aligned with the current Grade 12 subjects in the NSC examination (Kraak and Press 2008) for the period 2010 to 2014.

\section{Gender}

Table 2 illustrates the gender of 3075 first-year Accounting I students. In 2010, 56.8 per cent were female and 43.2 per cent male; in 2011 a decrease was noted in the number of females (51.2\%) and an increase in males (48.8\%); in 2012 a further decrease in female students to 47.3 per cent and a further increase in male students to 52.7 per cent was noted; while, in 2013, the ratio between female and male was similar to that of 2010, with 55.6 per cent female and 44.4 per cent male students and in 201454.2 per cent females, a small decrease from the previous year and 45.8 per cent males, a slight increase from 2013. The overall ratio for the period under review was 53.2 per cent female and 46.8 per cent male students.

Table 2: First-year Accounting students 2010 to 2014: gender profile

\begin{tabular}{|c|c|c|c|c|}
\hline \multirow{2}{*}{\multicolumn{2}{|c|}{ Year }} & \multicolumn{2}{|c|}{ Gender } & \multirow{2}{*}{ Total } \\
\hline & & Female & Male & \\
\hline \multirow[t]{3}{*}{2010} & Count & 267 & 203 & 470 \\
\hline & $\%$ within 2010 Year & 56.8 & 43.2 & 100.0 \\
\hline & $\%$ of Total & 8.6 & 6.5 & 15.1 \\
\hline \multirow[t]{3}{*}{2011} & Count & 249 & 240 & 489 \\
\hline & $\%$ within 2011 Year & 50.9 & 49.1 & 100.0 \\
\hline & $\%$ of Total & 8.1 & 7.7 & 15.8 \\
\hline \multirow[t]{3}{*}{2012} & Count & 241 & 268 & 509 \\
\hline & $\%$ within 2012 Year & 47.3 & 52.7 & 100.0 \\
\hline & $\%$ of Total & 7.8 & 8.6 & 16.4 \\
\hline \multirow[t]{3}{*}{2013} & Count & 365 & 291 & 656 \\
\hline & $\%$ within 2013 Year & 55.6 & 44.4 & 100.0 \\
\hline & $\%$ of Total & 11.7 & 9.4 & 21.1 \\
\hline \multirow[t]{3}{*}{2014} & Count & 515 & 436 & 951 \\
\hline & $\%$ within 2014 Year & 53.8 & 46.2 & 100.0 \\
\hline & $\%$ of Total & 17.0 & 14.6 & 31.6 \\
\hline \multicolumn{2}{|l|}{ Total } & 1637 & 1438 & 3075 \\
\hline \multicolumn{2}{|c|}{$\%$ within Year } & 53.2 & 46.8 & 100.0 \\
\hline \multicolumn{2}{|c|}{$\%$ of Total } & 53.2 & 46.8 & 100.0 \\
\hline
\end{tabular}


A $t$-test was conducted to compare the first-year Accounting students' Accounting I mark for female and male students over the period 2010 to 2014. The findings confirmed that there was no significant difference in the marks between females $(\mathrm{M}=57.73$, $\mathrm{SD}=13.094)$ and males $(\mathrm{M}=57.47, \mathrm{SD}=13.483 ; t(3073)=.555, p=.579)$. In contrast with this study, the results of the study by Wally-Dima and Mbekomiza $(2013,23)$ revealed that females outperform males in terms of their academic performance.

\section{Race}

Table 3 illustrates the different race groups of the 3075 first-year Accounting I students for the period 2010 to 2014. Black students comprised the largest group at 56.8 per cent, followed by Indian students at 23.6 per cent and white students at 15.3 per cent in 2010 . While in 2011, a slight decrease in the percentage of black students (55.2\%) was noted and a slight increase in Indian (24.5\%) and white students (15.7\%) compared to the previous year. However, in 2012, black students increased further to 60.9 per cent, while Indian (20.6\%) and white $(15.7 \%)$ students decreased in comparison with the preceding year. By 2013, black (66.2\%) students had increased dramatically from 2010, while in contrast the proportion of Indian (16.8\%) and white (13.6\%) students had decreased further. In 2014, the black group increased further to 67.3 per cent while the white group decreased to 9.1 per cent. The overall race group ratio for the period under review was as follows: black 62.5 per cent, Indian 20.4 per cent, white 13.2 per cent, with other race groups, that is, coloured and Chinese, comprising 2.7 per cent and 1.3 per cent respectively.

Table 3: First-year Accounting students 2010 to 2014: Race profile

\begin{tabular}{|c|c|c|c|c|c|c|c|}
\hline \multirow{2}{*}{\multicolumn{2}{|c|}{ Year }} & \multicolumn{5}{|c|}{ Race } & \multirow{2}{*}{ Total } \\
\hline & & Black & Chinese & Coloured & Indian & White & \\
\hline \multirow[t]{3}{*}{2010} & Count & 267 & 9 & 11 & 111 & 72 & 470 \\
\hline & $\%$ within 2010 Year & 56.8 & 1.9 & 2.3 & 23.6 & 15.3 & 100.0 \\
\hline & $\%$ of Total & 8.6 & 0.3 & 0.4 & 3.6 & 2.3 & 15.1 \\
\hline \multirow[t]{3}{*}{2011} & Count & 270 & 5 & 17 & 120 & 77 & 489 \\
\hline & \% within Year 2011 & 55.2 & 1.0 & 3.5 & 24.5 & 15.7 & 100.0 \\
\hline & $\%$ of Total & 8.8 & 0.2 & 0.5 & 3.9 & 2.5 & 15.9 \\
\hline \multirow[t]{3}{*}{2012} & Count & 310 & 6 & 8 & 105 & 80 & 509 \\
\hline & \% within Year 2012 & 60.9 & 1.2 & 1.6 & 20.6 & 15.7 & 100.0 \\
\hline & $\%$ of Total & 10.0 & 0.2 & 0.3 & 3.4 & 2.6 & 16.4 \\
\hline \multirow[t]{3}{*}{2013} & Count & 434 & 9 & 14 & 110 & 89 & 656 \\
\hline & $\%$ within Year 2013 & 66.2 & 1.4 & 2.1 & 16.7 & 13.5 & 100.0 \\
\hline & $\%$ of Total & 14.1 & 0.3 & 0.5 & 3.5 & 2.9 & 21.3 \\
\hline \multirow[t]{3}{*}{2014} & Count & 640 & 10 & 32 & 182 & 87 & $98 \backslash 51$ \\
\hline & \% within Year 2014 & 67.3 & 1.0 & 3.3 & 19.1 & 9.1 & 100.0 \\
\hline & $\%$ of Total & 20.8 & 0.3 & 1.0 & 5.9 & 2.8 & 30.9 \\
\hline \multicolumn{2}{|l|}{ Count } & 1921 & 39 & 82 & 628 & 405 & 3075 \\
\hline \multicolumn{2}{|c|}{$\%$ within Year } & 62.5 & 1.3 & 2.7 & 20.4 & 13.2 & 100.0 \\
\hline \multicolumn{2}{|c|}{$\%$ of Total } & 62.5 & 1.3 & 2.7 & 20.4 & 13.2 & 100.0 \\
\hline
\end{tabular}


An ANOVA between race groups was conducted to explore the impact of the different race groups on the Accounting I marks of first-year students. The ANOVA results indicate a statistically significant different at the $p<.01$ level in the Accounting marks of the five race groups: $\mathrm{F}(4,3070)=8.785, p=.000$. Post hoc comparisons, using the Tukey HSD test (as per Table 4), indicated a significant difference between the black $(M=56.71, S D=12.641)$ and Indian ( $\mathrm{M}=58.68, \mathrm{SD}=13.731)$ students' Accounting I marks, also between the black $(\mathrm{M}=$ $56.71, \mathrm{SD}=12.641)$ and white students' $(\mathrm{M}=60.59, \mathrm{SD}=15.103)$ Accounting I marks and between the white $(\mathrm{M}=60.59, \mathrm{SD}=15.103)$ and coloured $(\mathrm{M}=55.82, \mathrm{SD}=12.074)$ students' Accounting I marks. None of the other race groups showed any significance difference relating to Accounting I marks.

Table 4: Post hoc comparisons of race groups of first-year Accounting students 2010 to 2014

\begin{tabular}{|c|c|c|c|c|}
\hline (I) Race Group & (J) Race Group & Mean Difference (I-J) & Std. Error & Sig. \\
\hline \multirow[t]{4}{*}{1 Black } & 2 Indian & $-1.969^{*}$ & .607 & .010 \\
\hline & 3 White & $-3.879^{*}$ & .722 & .000 \\
\hline & 4 Coloured & .892 & 1.490 & .975 \\
\hline & 5 Chinese & -.804 & 2.137 & .996 \\
\hline \multirow[t]{4}{*}{2 Indian } & 1 Black & $1.969^{*}$ & .607 & .010 \\
\hline & 3 White & -1.909 & .842 & 156 \\
\hline & 4 Coloured & 2.861 & 1.551 & .348 \\
\hline & 5 Chinese & 1.166 & 2.180 & .984 \\
\hline \multirow[t]{4}{*}{3 White } & 1 Black & $3.879^{*}$ & .722 & .000 \\
\hline & 2 Indian & 1.909 & .842 & .156 \\
\hline & 4 Coloured & $4.771^{*}$ & 1.600 & .024 \\
\hline & 5 Chinese & 3.075 & 2.215 & .635 \\
\hline \multirow[t]{4}{*}{4 Coloured } & 1 Black & -.892 & 1.490 & .975 \\
\hline & 2 Indian & -2.861 & 1.551 & .348 \\
\hline & 3 White & $-4.771^{*}$ & 1.600 & .024 \\
\hline & 5 Chinese & -1.696 & 2.569 & .965 \\
\hline \multirow[t]{4}{*}{5 Chinese } & 1 Black & .804 & 2.137 & .996 \\
\hline & 2 Indian & -1.166 & 2.180 & .984 \\
\hline & 3 White & -3.075 & 2.215 & .635 \\
\hline & 4 Coloured & 1.696 & 2.569 & .965 \\
\hline
\end{tabular}

\section{Language}

Table 5 illustrates the various languages recorded as Grade 12 subjects of the 3075 first-year accounting students. A total of 22 different languages were recorded including the eleven official South African languages and eleven languages other than the official South African languages. English as first language obtained a mean score of MD $=72.89$ and was the most representative at 72.55 per cent, followed by Afrikaans as a first additional language (MD = 
69.19) and thereafter English as first additional language (MD = 73.84). Eleven other languages were also noted, French ( $\mathrm{MD}=71.95)$ being the most represented $(1.33 \%)$ of the total Accounting students followed by Hebrew (MD = 78.26) 1.01 per cent. The mean scores reflected in Table 5 are the students' marks obtained in the NSC exam. The highest mean for the official South African languages was IsiZulu First Language (MD = 80.79) and the lowest was Afrikaans Second Additional Language ( $\mathrm{MD}=68.80)$. The majority of students obtained high marks for languages in Grade 12.

Table 5: First-year Accounting students: language profile

\begin{tabular}{|c|c|c|c|}
\hline Language & $\mathbf{N}$ & Mean & $\%$ \\
\hline \multicolumn{4}{|l|}{ Official South African Language } \\
\hline English First Language & 2231 & 72.98 & 72.55 \\
\hline Afrikaans First Additional & 1885 & 69.19 & 61.30 \\
\hline English First Additional Language & 844 & 73.84 & 27.45 \\
\hline IsiZulu First Additional Language & 237 & 75.77 & 7.71 \\
\hline IsiZulu First Language & 254 & 80.79 & 8.26 \\
\hline Sepedi First Language & 195 & 75.89 & 6.34 \\
\hline Setswana First Language & 118 & 72.22 & 3.84 \\
\hline Tshivenda First Language & 85 & 78.42 & 2.76 \\
\hline IsiXhosa First Language & 66 & 73.89 & 2.15 \\
\hline Xitsonga First Language & 61 & 80.36 & 1.98 \\
\hline Sesotho First Language & 55 & 76.16 & 1.79 \\
\hline Afrikaans Second Additional Language & 25 & 68.80 & 0.81 \\
\hline Sepedi First Additional Language & 17 & 75.29 & 0.55 \\
\hline IsiXhosa First Additional Language & 16 & 76.50 & 0.52 \\
\hline SiSwati First Additional Language & 13 & 80.46 & 0.42 \\
\hline SiSwati First Language & 14 & 79.21 & 0.46 \\
\hline Afrikaans First Language & 10 & 77.00 & 0.33 \\
\hline Setswana First Additional Language & 8 & 69.38 & 0.26 \\
\hline English Advanced & 8 & 72.13 & 0.26 \\
\hline Sesotho First Additional Language & 7 & 73.86 & 0.23 \\
\hline IsiNdebele First Language & 5 & 79.00 & 0.16 \\
\hline Tshivenda First Additional Language & 2 & 73.00 & 0.07 \\
\hline \multicolumn{4}{|l|}{ Other Languages } \\
\hline French & 41 & 71.95 & 1.33 \\
\hline Hebrew & 31 & 78.26 & 1.01 \\
\hline Greek & 10 & 76.10 & 0.33 \\
\hline German & 9 & 76.67 & 0.29 \\
\hline Portuguese & 6 & 69.00 & 0.20 \\
\hline Chinese & 5 & 84.40 & 0.16 \\
\hline Arabic & 3 & 66.67 & 0.10 \\
\hline Italian & 4 & 70.25 & 0.13 \\
\hline Gujarati Second Additional Language & 3 & 85.00 & 0.10 \\
\hline Latin & 1 & 80.00 & 0.03 \\
\hline Spanish & 1 & 83.00 & 0.03 \\
\hline
\end{tabular}




\section{Choice of Grade 12 Subjects}

Table 6 illustrates the various Grade 12 subjects for the 3075 first-year Accounting students for 2010 to 2014, a total of 29 subjects excluding the languages mentioned in Table 5. Three compulsory NSC subjects, Mathematics (not Mathematical Literacy), Life Orientation and English, are required to be considered for admission to the BCom (General) and BCom (Accounting) degrees. Moreover, an average of 60 per cent or higher, for both Mathematics and English (English as first or first additional language) was required to qualify to register for these degrees.

The findings of Oosthuizen and Eiselen (2012) emphasise the importance of a minimum of 60 per cent in NSC Mathematics as an admission requirement for the Accounting programme (Smith and Naylor 2001). The requirements for these degrees do not, however, stipulate whether Grade 12 English has to be English as first or a first additional language. According to Table 4, 72.55 per cent of students had English as a first language and 27.45 per cent of students had English as a first additional language. In English (both first and first additional), students obtained an average of 73.41 per cent in the NSC exam. It should also be noted here that, according to Table 5, one of the six students who obtained 81.0 per cent for Mathematical Literacy was accepted into the Accounting I course as the other five students had both Mathematics and Mathematical Literacy as Grade 12 subjects subsequently the student that had Mathematical Literacy failed Accounting I. Apart from the languages and the requisite Grade 12 subjects, the following subjects were most popular among the BCom (General and Accounting) degree students: Accounting (84.49\%), Physical Science (62.89\%), Life Sciences (44.98\%), Business Studies (39.61\%), Mathematics Paper 3 (33.40\%) and Economics (23.28\%). Students' marks varied among these subjects from 60 per cent and upwards.

Table 6: First-year Accounting students: Grade 12 subjects

\begin{tabular}{|l|c|c|c|}
\hline Grade 12 Subjects & N & Mean & \% \\
\hline Life Orientation & 3075 & 82.11 & 100.00 \\
\hline Mathematics & 3073 & 75.26 & 99.93 \\
\hline Accounting & 2598 & 80.36 & 84.49 \\
\hline Physical Science & 1934 & 69.93 & 62.89 \\
\hline Life Sciences & 1383 & 76.34 & 44.98 \\
\hline Business Studies & 1218 & 78.75 & 39.61 \\
\hline Mathematics Paper 3 & 1027 & 62.40 & 33.40 \\
\hline Economics & 716 & 79.25 & 23.28 \\
\hline Geography & 441 & 76.41 & 14.34 \\
\hline History & 298 & 77.41 & 9.69 \\
\hline Computer Applications Techniques & 196 & 74.45 & 6.37 \\
\hline Information Technology & 189 & 71.06 & 6.15 \\
\hline
\end{tabular}




\begin{tabular}{|l|r|r|c|}
\hline Grade 12 Subjects & N & Mean & \% \\
\hline $\begin{array}{l}\text { Mathematics Advanced } \\
\text { Programming }\end{array}$ & 121 & 63.95 & 3.93 \\
\hline Engineering Graphics \& Design & 61 & 73.49 & 1.98 \\
\hline Consumer Studies & 51 & 72.18 & 1.66 \\
\hline Tourism & 44 & 79.07 & 1.43 \\
\hline Art Dramatic & 41 & 82.02 & 1.33 \\
\hline Art Visual & 30 & 72.30 & 0.98 \\
\hline Religious Study & 28 & 87.79 & 0.91 \\
\hline Agricultural Management Practice & 23 & 70.30 & 0.75 \\
\hline Agricultural Sciences & 15 & 73.40 & 0.49 \\
\hline Music & 11 & 70.82 & 0.36 \\
\hline Hospitality Study & 10 & 74.30 & 0.33 \\
\hline Design & 8 & 75.25 & 0.26 \\
\hline Mathematical Literacy & 6 & 85.83 & 0.20 \\
\hline Electrical Technology & 5 & 77.40 & 0.16 \\
\hline Civil Technology & 4 & 64.50 & 0.13 \\
\hline Mechanical Technology & 2 & 64.00 & 0.07 \\
\hline Maritime Economics & 2 & 67.00 & 0.07 \\
\hline
\end{tabular}

\section{Impact of choice of Grade 12 subjects on the marks obtained in Accounting 1}

Table 7 illustrates a cross tabulation of each of the 62 Grade 12 subjects (in alpha order) and the marks obtained in Accounting I. Table 7 contains the frequency of each subject together with the associated correlation coefficient significance. A very high significant correlation was found between the following subjects and Accounting I marks: Accounting (.512), Physical Science (.462), Afrikaans First Additional language (.459), Mathematics Advanced Programming (.459), Mathematics (.455), Life Sciences (.451), History (.412), Information Technology (.411), Economics (.399), Mathematics Paper 3 (.392), Business Studies (.349), Geography (.348), English First Language (.299), English First Additional Language (.230), Computer Applications Techniques (.231) and Life Orientation (.210). These highly significant correlations demonstrate that students who obtained high Grade 12 subject marks obtained higher Accounting I marks than students with lower Grade 12 subject marks. Oosthuizen and Eiselen's (2012) findings confirm that NSC Mathematics marks are strongly associated with success in first-year Accounting. However, it was surprising to note that Life Orientation, as a compulsory Grade 12 subject, also correlates with a higher Accounting I mark. Moreover, the results of the study by Addow et al. (2013) confirm that English language proficiency correlates positively with academic success. Tailab (2013) confirmed that one of the major obstacles identified was students’ lack of English language proficiency. Further, Aidoo-Buameh and Ayagre (2013) concluded a relationship was found between Mathematics at pre-university level and academic performance but found no correlation between pre-university English and 
academic performance. In addition, a significant correlation was found between the following subjects and Accounting I marks: Dramatic Art (.349), Visual Art (.622), Sepedi First Language (.164) and Sesotho First Language (.325). Interestingly, for the period 2010 to 2013, no correlations was found between Accounting I students' academic performance and languages other than English and Afrikaans but in 2014 significant correlations were found between Accounting I students' academic performance and two first languages; Sepedi and Sesotho. It is of interest to note that students who had Dramatic Art and Visual Art as Grade 12 subjects, that are practically orientated subjects, that need creative thinking and application had an impact on the Accounting I marks.

Table 7: Cross tabulation between Grade 12 subjects and Accounting 1 marks

\begin{tabular}{|c|c|c|c|}
\hline Grade 12 Subject & $\begin{array}{l}\text { Correlation } \\
\text { Coefficient }\end{array}$ & Sig. (2-tailed) & $\mathbf{N}$ \\
\hline Accounting & $.512^{\star \star}$ & .000 & 2598 \\
\hline Afrikaans First Additional language & $.459^{\star \star}$ & .000 & 1885 \\
\hline Afrikaans First Language & .411 & .272 & 10 \\
\hline Afrikaans Second Additional Language & -.278 & .179 & 25 \\
\hline Agricultural Management Practice & .177 & .419 & 23 \\
\hline Agricultural Sciences & -.095 & .737 & 15 \\
\hline Arabic & .500 & .667 & 3 \\
\hline Art Dramatic & $.349^{*}$ & .025 & 41 \\
\hline Art Visual & $.622^{*}$ & .000 & 30 \\
\hline Business Studies & $.349^{\star \star}$ & .000 & 1218 \\
\hline Chinese & -.213 & .731 & 5 \\
\hline Civil Technology & .621 & .379 & 4 \\
\hline Computer Applications Techniques & $.231^{\star \star}$ & .001 & 196 \\
\hline Consumer Studies & .266 & .059 & 51 \\
\hline Design & .232 & .581 & 8 \\
\hline Economics & $.399^{* \star}$ & .000 & 716 \\
\hline Electrical Technology & .233 & .707 & 5 \\
\hline Engineering Graphics \& Design & .211 & .102 & 61 \\
\hline English Advanced & .198 & .638 & 8 \\
\hline English First Additional Language & $.230^{\star \star}$ & .000 & 844 \\
\hline English First Language & $.299^{\star \star}$ & .000 & 2231 \\
\hline French & .199 & .212 & 41 \\
\hline Geography & $.348^{\star \star}$ & .000 & 441 \\
\hline German & -.297 & .437 & 9 \\
\hline Greek & -.021 & .954 & 10 \\
\hline Gujarati Second Additional Language & .381 & .751 & 3 \\
\hline Hebrew & .225 & .223 & 31 \\
\hline History & $.412^{\star \star}$ & .000 & 298 \\
\hline Hospitality Study & .503 & .138 & 10 \\
\hline Information Technology & $.411^{\star *}$ & .000 & 189 \\
\hline IsiNdebele First Language & -.029 & .963 & 5 \\
\hline
\end{tabular}




\begin{tabular}{|c|c|c|c|}
\hline Grade 12 Subject & $\begin{array}{l}\text { Correlation } \\
\text { Coefficient }\end{array}$ & Sig. (2-tailed) & $\mathbf{N}$ \\
\hline IsiXhosa First Additional Language & .355 & .093 & 16 \\
\hline IsiXhosa First Language & .093 & .458 & 66 \\
\hline IsiZulu First Additional Language & -.028 & .657 & 254 \\
\hline IsiZulu First Language & .011 & .092 & 237 \\
\hline Italian & .517 & .483 & 4 \\
\hline Latin & & c & 1 \\
\hline Life Orientation & $.210^{\star \star}$ & .000 & 3075 \\
\hline Life Sciences & $.451^{\star \star}$ & .000 & 1383 \\
\hline Maritime Economics & $1.000^{\star \star}$ & & 2 \\
\hline Mathematical Literacy & .185 & .691 & 7 \\
\hline Mathematics & $.455^{\star \star}$ & .000 & 3073 \\
\hline Mathematics Advanced Programming & $.459^{\star \star}$ & .303 & 121 \\
\hline Mathematics Paper 3 & $.392^{\star \star}$ & .000 & 1027 \\
\hline Mechanical Technology & & c & 2 \\
\hline Music & .042 & .901 & 11 \\
\hline Physical Science & $.462^{\star \star}$ & .000 & 1934 \\
\hline Portuguese & -.488 & .326 & 6 \\
\hline Religious Study & .162 & .410 & 28 \\
\hline Sepedi First Additional Language & .357 & .160 & 17 \\
\hline Sepedi First Language & $.164^{*}$ & .022 & 195 \\
\hline Sesotho First Additional Language & -.575 & .177 & 7 \\
\hline Sesotho First Language & $.325^{*}$ & .016 & 55 \\
\hline Setswana First Additional Language & .192 & .648 & 8 \\
\hline Setswana First Language & .027 & .772 & 118 \\
\hline SiSwati First Additional Language & -.267 & .377 & 13 \\
\hline SiSwati First Language & .270 & .351 & 14 \\
\hline Spanish & & C & 1 \\
\hline Tourism & .236 & .123 & 44 \\
\hline Tshivenda First Additional Language & $1.000^{\star \star}$ & & 2 \\
\hline Tshivenda First Language & .179 & .100 & 85 \\
\hline Xitsonga First Language & .046 & .723 & 61 \\
\hline
\end{tabular}

**. Correlation is significant at the 0.01 level (2-tailed).

*. Correlation is significant at the 0.05 level (2-tailed).

c. Cannot be computed because at least one of the variables is constant.

\section{Accounting as a Grade 12 subject}

As shown in Table 6, 84.49 per cent of the first-year Accounting students had Accounting as a Grade 12 subject obtained a mean of 80.36 . Table 8 illustrates that of the 2598 students who had Accounting as a Grade 12 subject 82.10 per cent passed and 17.90 per cent failed Accounting I. The findings further illustrate that of the 477 students who had not had Accounting as a Grade 12 subject 60.16 per cent passed and 39.84 per cent failed Accounting I. In Figure 2, the trend from 2010 to 2014 indicates that more students failed Accounting I with no Accounting in Grade 12 than students who passed Accounting I. Furthermore, Figure 3 
shows that more students with Accounting as a Grade 12 subject passed Accounting I, indicating an increasing trend from 2010 to 2014.

Table 8: First-year Accounting students that passed or failed Accounting who had Accounting or no Accounting as a Grade 12 subject

\begin{tabular}{|c|c|c|c|c|c|c|}
\hline \multirow{2}{*}{\multicolumn{4}{|c|}{ Accounting I Pass or Fail }} & \multicolumn{2}{|c|}{ Accounting 2 Groups } & \multirow{3}{*}{$\begin{array}{r}\text { Total } \\
114\end{array}$} \\
\hline & & & & \multirow{2}{*}{$\frac{\text { No Accounting }}{21}$} & \multirow{2}{*}{$\begin{array}{c}\text { Accounting } \\
93\end{array}$} & \\
\hline \multirow[t]{17}{*}{1 Fail } & \multirow[t]{15}{*}{ Year } & \multirow[t]{3}{*}{2010} & Count & & & \\
\hline & & & \% within Year & 18.4 & 81.6 & 100.0 \\
\hline & & & \begin{tabular}{|l}
$\%$ of Total \\
\end{tabular} & 3.2 & 14.2 & 17.4 \\
\hline & & \multirow[t]{3}{*}{2011} & Count & 14 & 56 & 70 \\
\hline & & & \begin{tabular}{|l|}
$\%$ within Year \\
\end{tabular} & 20.0 & 80.0 & 100.0 \\
\hline & & & $\%$ of Total & 2.1 & 8.5 & 10.7 \\
\hline & & \multirow[t]{3}{*}{2012} & Count & 31 & 59 & 90 \\
\hline & & & $\%$ within Year & 34.4 & 65.6 & 100.0 \\
\hline & & & \% of Total & 4.7 & 9.0 & 13.7 \\
\hline & & \multirow[t]{3}{*}{2013} & Count & 61 & 130 & 191 \\
\hline & & & \% within Year & 31.9 & 68.1 & 100.0 \\
\hline & & & $\%$ of Total & 9.3 & 19.8 & 29.2 \\
\hline & & \multirow[t]{3}{*}{2014} & Count & 63 & 127 & 190 \\
\hline & & & \% within Year & 33.2 & 66.8 & 100.0 \\
\hline & & & \% of Total & 9.6 & 19.4 & 29.0 \\
\hline & \multirow{2}{*}{\multicolumn{2}{|c|}{ Total }} & Count & 190 & 465 & 655 \\
\hline & & & \% of Total & 29.0 & 71.0 & 100.0 \\
\hline \multirow[t]{17}{*}{2 Pass } & \multirow[t]{15}{*}{ Year } & \multirow[t]{3}{*}{2010} & Count & 47 & 309 & 356 \\
\hline & & & \% within Year & 13.2 & 86.8 & 100.0 \\
\hline & & & \% of Total & 1.9 & 12.8 & 14.7 \\
\hline & & \multirow[t]{3}{*}{2011} & Count & 50 & 369 & 419 \\
\hline & & & \% within Year & 11.9 & 88.1 & 100.0 \\
\hline & & & $\%$ of Total & 2.1 & 15.2 & 17.3 \\
\hline & & \multirow[t]{3}{*}{2012} & Count & 69 & 350 & 419 \\
\hline & & & \% within Year & 16.5 & 83.5 & 100.0 \\
\hline & & & $\%$ of Total & 2.9 & 14.5 & 17.3 \\
\hline & & \multirow[t]{3}{*}{2013} & Count & 35 & 430 & 465 \\
\hline & & & \% within Year & 7.5 & 92.5 & 100.0 \\
\hline & & & \% of Total & 1.4 & 17.8 & 19.2 \\
\hline & & 2014 & Count & 86 & 675 & 761 \\
\hline & & & \% within Year & 11.3 & 88.7 & 100.0 \\
\hline & & & \% of Total & 3.6 & 27.9 & 31.4 \\
\hline & Total & & Count & 287 & 2133 & 2420 \\
\hline & & & $\%$ of Total & 11.9 & 88.1 & 100.0 \\
\hline Total & Year & 2010 & Count & 68 & 402 & 470 \\
\hline & & & \% within Year & 14.5 & 85.5 & 100.0 \\
\hline & & & \% of Total & 2.2 & 13.1 & 15.3 \\
\hline & & 2011 & Count & 64 & 425 & 489 \\
\hline & & & \% within Year & 13.1 & 86.9 & 100.0 \\
\hline & & & $\%$ of Total & 2.1 & 13.8 & 15.9 \\
\hline & & 2012 & Count & 100 & 409 & 509 \\
\hline & & & \% within Year & 19.6 & 80.4 & 100.0 \\
\hline & & & $\%$ of Total & 3.3 & 13.3 & 16.6 \\
\hline & & 2013 & Count & 96 & 560 & 656 \\
\hline & & & \% within Year & 14.6 & 85.4 & 100.0 \\
\hline & & & $\%$ of Total & 3.1 & 18.2 & 21.3 \\
\hline & & 2014 & Count & 149 & 802 & 951 \\
\hline & & & \% within Year & 15.7 & 84.3 & 100.0 \\
\hline & & & $\%$ of Total & 4.8 & 26.1 & 30.9 \\
\hline & Total & & Count & 477 & 2598 & 3075 \\
\hline & & & \% of Total & 15.5 & 84.5 & 100.0 \\
\hline
\end{tabular}




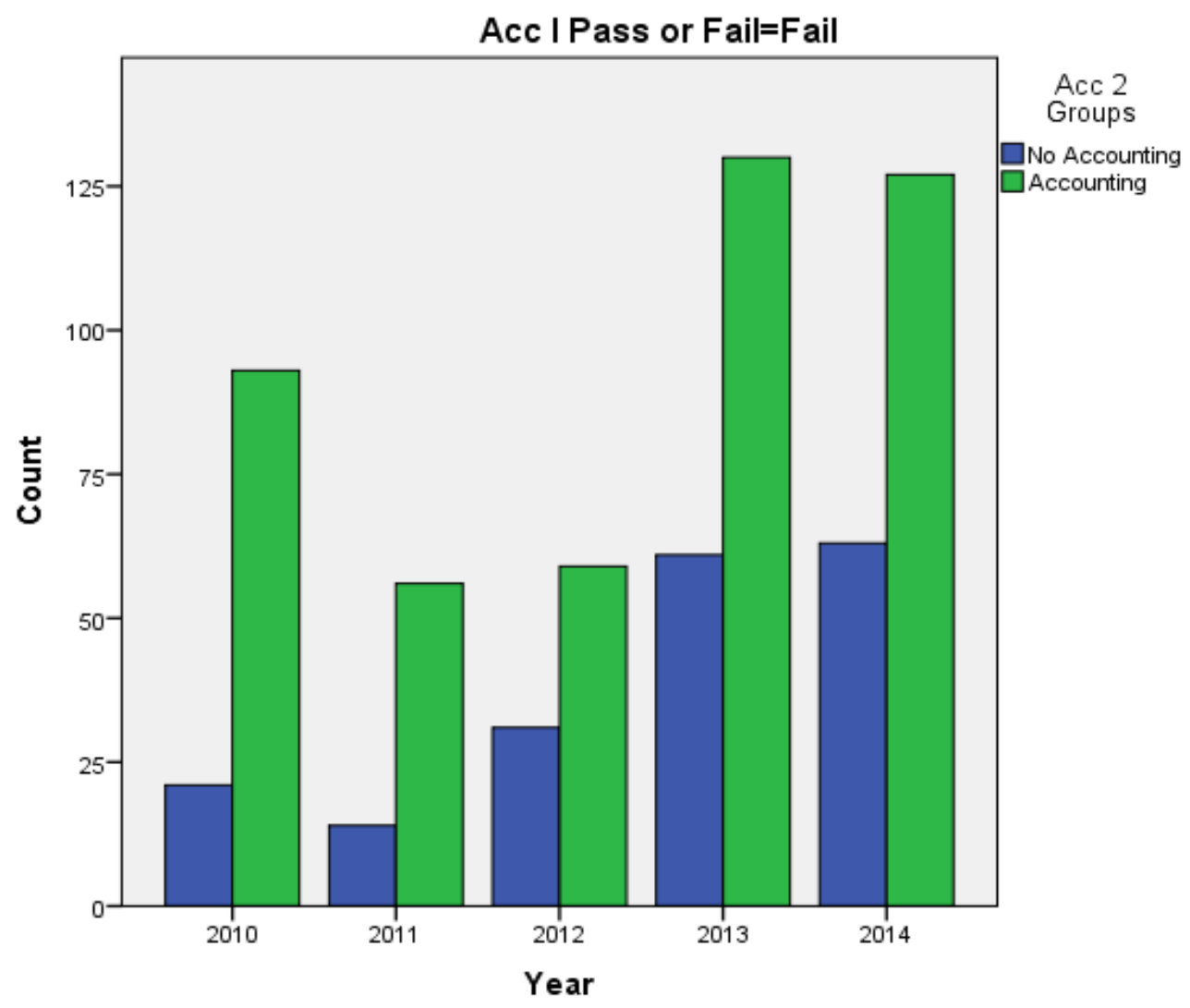

Figure 2: Students failed Accounting I in 2013-2014: First-year Accounting I students that had Accounting or no Accounting as a Grade 12 subject

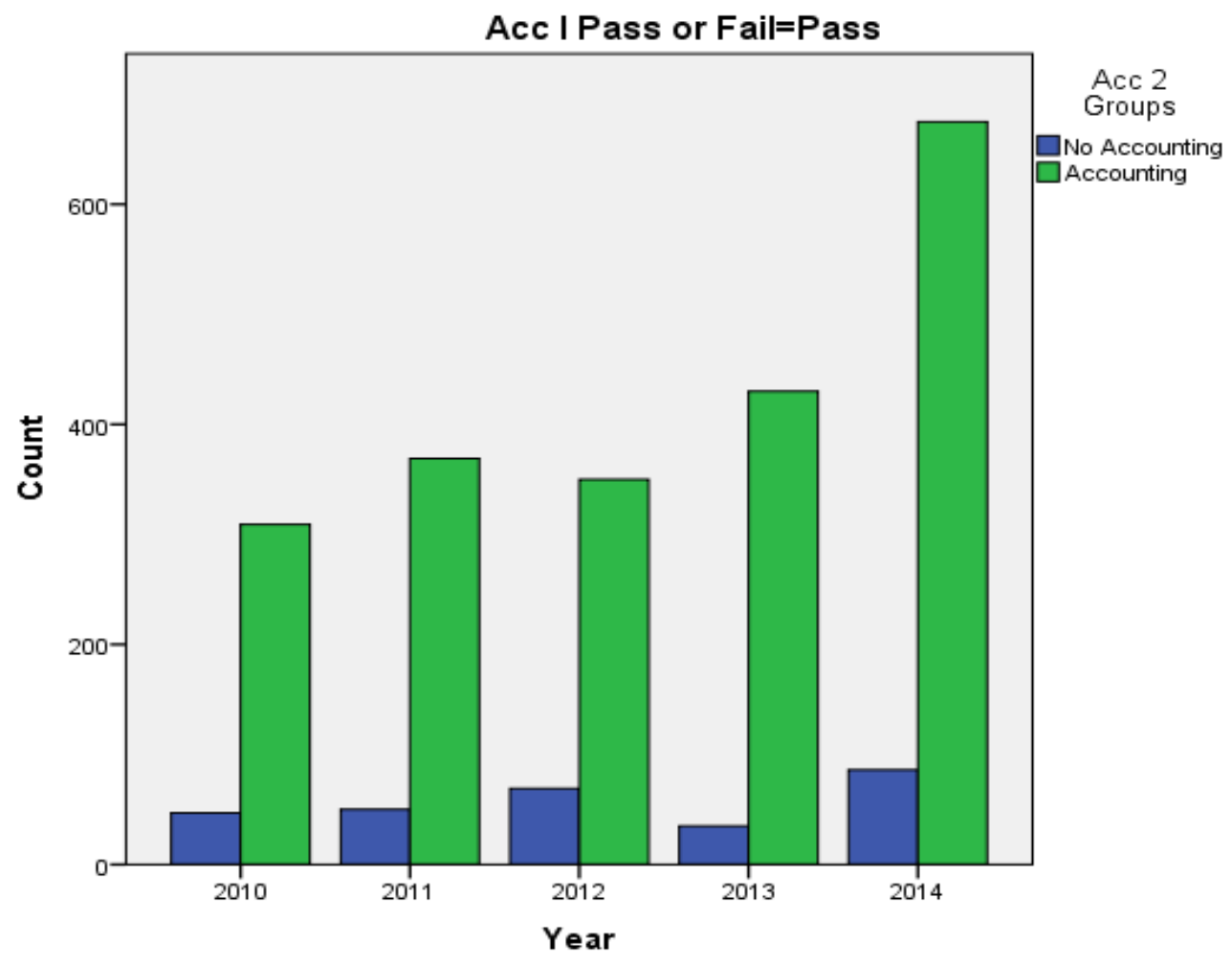

Figure 3: Students passed Accounting I in 2010-2014: First-year Accounting students that had Accounting or no Accounting as a Grade 12 subject 
A $t$-test was conducted to compare the first-year Accounting students' Accounting I marks in terms of whether or not students had Accounting in Grade 12. The results confirmed a very high significant difference in the marks of students who had Accounting in Grade $12(\mathrm{M}=$ 59.04, $\mathrm{SD}=12.385)$ and students who did not have Accounting in Grade $12(\mathrm{M}=49.79, \mathrm{SD}=$ 15.127; $\mathrm{t}(3073)=-14.458, \mathrm{p}=.000)$. This finding confirms with the finding of Aidoo-Buameh and Ayagre (2013) of a statistically significant relationship between prior Accounting knowledge and academic performance. Furthermore, one of the recommendations by Akenbor (2014) was that pre-university Accounting with a minimum pass of $60 \%$, as a key success factor to achieve in Accounting, should be part of the requirements for admitting students to the Accounting programme.

\section{CONCLUSION}

This study explored the first-year Accounting students' demographics and pre-university knowledge versus academic performance in Accounting I over a period of five years at a South African university. The objectives of this study were to determine whether students' profile and pre-university knowledge consisting of age, gender, race, language, choice of Grade 12 subjects and whether students had Accounting as a Grade 12 subject, had an effect on first-year accounting students’ academic performance.

Six research statements were addressed in determining whether age, gender, race, language, choice of Grade 12 subjects and whether students had Accounting as a Grade 12 subject influenced students' academic performance (measured in terms of marks obtained in Accounting I). The first variable was addressed, that is, the age of students, and the findings confirmed that the students' age, which in this study varied from 19 and 21 years, had no impact on the students' marks obtained in Accounting 1. Students studying part time were excluded from the study since Grade 12 subjects prior to 2010 (which included higher and standard grades) were not aligned with the current Grade 12 subjects (Kraak and Press 2008).

The second variable that was addressed was the students' gender, and the findings confirmed no significant difference were found between students' Accounting I marks of females and males. The third variable that was addressed was the race of students, and the findings confirmed a significant difference between black Accounting I students' marks and both Indian and white students, and also between Accounting I students' marks of white and coloured students. No significance difference in Accounting I marks was apparent for any of the other 
race groups indicated.

The fourth variable that was investigated was the language of students. In this regard, a very strong correlation was found between the following languages as a Grade 12 subject and Accounting I marks: English First Language, English First Additional Language, Afrikaans First Additional language. Furthermore, a significant correlation was found between the following two languages, Sepedi First Language and Sesotho First Language, with Accounting I marks.

The fifth variable that was addressed was the choice of Grade 12 subjects. In this regard, the statistical data confirmed that the higher the Grade 12 marks obtained in the NSC exam the higher the Accounting I marks. It was necessary to test this cross tabulation between the choice of Grade 12 subjects and the impact on Accounting I marks, not only to confirm that the choice of Grade 12 subject does matter but also to create awareness among students and career guidance teachers of which Grade 12 subjects could assist students to obtain higher marks in Accounting I and/or to pass Accounting I. The evidence confirmed that students at risk could be identified in order to enable the university to inform those students who fit the profile not to enrol for Accounting I or to make arrangements to fill the gap by passing or obtaining good Accounting I marks.

The final variable was then addressed, namely, whether students had Accounting as a Grade 12 subject. The findings in this regard confirmed students with Accounting as a Grade 12 subject tend to display high academic performance in Accounting I. Moreover, statistical tests confirmed that there was a very high significant difference in the students' Accounting I marks who had Accounting in Grade 12 and students with no Accounting in Grade 12. Students who are at risk because they did not have Accounting as a Grade 12 subject have the option to register for the pre-accounting school, which is offered at the beginning of the academic year. Furthermore, students at risk are identified at the beginning of the academic year and additional tutorials are made available to accommodate them. At these tutorials, attendance registers are kept so as to track at-risk students who do not attend the tutorials and/or to investigate reasons why students do not attend the tutorials.

\section{THE LIMITATIONS, RECOMMENDATIONS AND VALUE OF THE STUDY}

The study's limitations include, firstly, the use of only one university and, secondly, a sample 
size of only include first-year Accounting students. We recommend that further studies should investigate the impact of personal, financial and socioeconomic factors on the academic performance of Accounting students, as this will assist in providing a holistic view of the impact of other factors on students' academic performance in Accounting. This study is deemed to be valuable in that it should enable the university to identify students who fit the profile in terms of being able to pass Accounting I and to identify at-risk students to therefore offer additional support to enable these students to pass Accounting I.

\section{NOTE}

1. 'The National Senior Certificate or NSC is a high school diploma and is the school-leaving certificate in South Africa. This certificate is commonly known as the matriculation (matric) certificate, as grade 12 is the matriculation grade' (DoE 2015).

\section{REFERENCES}

Addow, A. M., A. H. Abubakar and M. S. Abukar. 2013. English language proficiency and academic achievement for undergraduate students in Somalia. Educational Research International 2(2): 59-66.

Aidoo-Buameh, J. and P. Ayagre. 2013. The effect of entry grades on academic performance of university Accounting students: A case of undergraduates on Central University College. Research Journal of Finance and Accounting 4(7): 198-206.

Akenbor, C. O. 2014. Institutional factors influencing the academic performance of students in principles of Accounting. International Journal of Higher Education 1(1): 15-26.

Baard, R. S., L. P. Steenkamp, B. L. Frick and K. Kidd. 2010. Factors influencing success in first-year Accounting at a South African University: The profile of a successful first-year Accounting student. South African Journal of Accounting Research 24(1): 129-147.

Balduf, M. 2009. Underachievement among college students. Journal of Advanced Academics 20(2): 274294.

Barlett, S., M. J. Peel and M. Pendlebury. 1993. From fresher to finalist: A three-year analysis of student performance on an Accounting Degree Programme. Accounting Education: An International Journal 2(2): 111-122.

Biggs, J. B. 1985. The role of metalearning in study processes. British Journal of Educational Psychology 55(2): 185-212.

Biggs, J. 1993. What do inventories of students' learning process really measure? A theoretical review and clarification. British Journal of Educational Psychology 63: 3-19.

Booth, P., P. Luckett and R. Mladenovic. 1999. The quality of learning in Accounting education: The impact of approaches to learning on academic performance. Accounting Education: An International Journal 8(4): 277-300.

Bullock-Yowell, E., G. W. Peterson, R. C. Reardon, S. J. Leierer and C. A. Reed. 2011. Relationships among career and life stress, negative career thought, and career decision state: A cognitive information processing perspective. Career Development Quarterly, 59: 302-314.

Department of Education. 2002. A new Academic Policy for Programmes and Qualifications in Higher Education. https://www.ru.ac.za/media/rhodesuniversity/content/institutionalplanning/ documents/New\%20Academic\%20Policy\%20on\%20Programmes\%20\&\%20Qualifications\%202002. pdf (accessed 4 April 2016).

Department of Education. 2015. http://ncedu.ncape.gov.za/index.php/teacher/national-senior-certificate (accessed 30 April 2016).

DoE see Department of Education. 
Duff, A. 2004. Understanding academic performance and progression of first-year Accounting and Business Economics undergraduates: The role of approaches to learning and pro academic achievement. Accounting Education 13(13): 409-30.

Du Plessis, A., H. Müller and P. Prinsloo. 2005. Determining the profile of the successful first-year Accounting student. South African Journal of Higher Education 19(4): 684-98.

Eddy, S. W., R. J. Burke and L. Fiksenbaum. 2008. Career choice in management: Findings from US MBA students. Career Development International 13(4): 346-361.

Fry, H., S. Ketteridge and S. Marshall. 2009. A handbook for teaching and learning in higher education. 3rd Edition. New York: Routledge.

Jordaan, Y., E. Burger and C. Smithard. 2009. Comparing levels of career indecision among selected honours degree students at the University of Pretoria. Meditari Accountancy Research 17(2): 85-100.

Kraak, A. and K. Press. 2008. Human Resources Development Review 2008: Education, employment and skills in South Africa. Cape Town: HSRC Press.

Lourens, A. and I. P. J. Smit. 2003. Retention: Predicting first year success. South African Journal of Higher Education 17(3): 169-76.

Mills, C., J. Heyworth, L. Rosenwax, S. Carr and M. Rosenberg. 2009. Factors associated with the academic success of first year Health Science students. Advances in Health Science Education 14: 205-17.

Müller, H., P. Prinsloo and A. du Plessis. 2007. Validating the profile of a successful first-year Accounting students. Meditari Accounting Research 15(1): 19-33.

Oosthuizen, A. and R. Eiselen. 2012. Factors associated with success in first-year Accounting after the implementation of the National Senior Certificate. Acta Academica 44(3): 156-74.

Papageorgiou, E., C. Callaghan, D. Coldwell and T. Joosub. 2014. Perceptions among professional Accounting students of self, job attractiveness and academic reputation. South African Journal of Accounting Research 28(1): 25-40.

Pitso, T. 2013. Status of scholarship of teaching and learning in South Africa. South African Journal of Higher Education 27(1): 196-209.

Prinsloo, P. and A. A. van Rooyen. 2007. Exploring a blended learning approach to improving student success in the teaching of second year Accounting. Meditari Accountancy Research 15(1): 51-65.

Rowlands, J. E. 1988. The effect of secondary school Accounting study on university Accounting performance. De Ratione 2(2): 17-21.

SAISA see South African Institute of Chartered Accountants.

Smith, J. and R. Naylor. 2001. Determinants of degree performance in UK universities: A statistical analysis of the 1993 student cohort. Oxford Bulletin of Economic and Statistics 63(1): 29-60.

South African Institute of Chartered Accountants. 2016. Training and education, training programme competencies. https://www.saica.co.za/Portals/0/Trainees/documents/SAICA (accessed 5 September 2016).

Steenkamp, L. P., R. S. Baard and B. L. Frick. 2009. Factors influencing success in first-year Accounting at a South African university: A comparison between lecturers' assumptions and students' perceptions. South African Journal of Accounting Research 23(1): 113-40.

Tailab, M. M. 2013. Difficulties of academic achievement in principles of Accounting Course from the student perspective: Evidence from Libya. Higher Education Studies 3(5): 36-46.

Wally-Dima, L. and C. L. Mbekomiza. 2013. Causes of gender differences in Accounting performance: Students’ perspective. International Education Studies 6(10): 13-26.

Weatherby, M., P. H. Winne, K. MacAllister and J. C. Nesbit. 2008. It's my life: A prescriptive decision model to help students explore, choose, and plan careers. Prepared for the Canadian Council of Learning (CCL). 